\title{
Evaluation of the Relationship Between Orthopedic Injuries and Attention Deficit Hyperactivity Disorder in Childhood and Adolescence
}

\section{Çocukluk ve Ergenlikte Ortopedik Yaralanmalar ve Dikkat Eksikliği Hiperaktivite Bozukluğu Arasındaki Ilişkinin Değerlendirilmesi}

\author{
(D) İsmail Gökhan ŞAHIN ${ }^{1}$, (D Leyla BOZATLI², (D Zeynep Anıl ŞAHIN³ , (D Işık GÖRKER² \\ ${ }_{1}^{1}$ Muğla Sıtkı Koçman Training and Research Hospital, Clinic of Orthopedics and Traumatology, Muğla, Turkey \\ 2Trakya University Medical Faculty Hospital, Department of Child and Adolescent Psychiatry, Edirne, Turkey \\ ${ }^{3}$ Muğla Sıtkı Koçman Training and Research Hospital, Child and Adolescent Psychiatry Clinic, Muğla, Turkey
}

\begin{abstract}
Aim: Attention deficit hyperactivity disorder (ADHD) is the most neurodevelopmental disorder in childhood, which causes repetitive trauma and extremity injuries. Oppositional defiant disorder (ODD) and conduct disorder (CD) are the most comorbid conditions of ADHD. Our study investigated the correlation between extremity trauma and ADHD's subgroups in pediatric trauma patients and comparison with the control group. Our aim was to detect high-risk patients in pediatric extremity injuries and to prevent possible extremity injuries with early diagnosis.

Materials and Methods: Between September 2018 and February 2019, 60 pediatric patients with extremity injuries (group 1) and non-traumatic reasons (group 2) were included in this prospective study consecutively. Patients were evaluated with the Conner's Parent Rating Scale and Strength and Difficulties Questionnaire for ADHD subgroups, ODD and CD. Patients who received an initial diagnosis were evaluated by the Child and Adolescent Psychiatry Department of Trakya University Medical Hospital.

Results: Patients who were diagnosed as ADHD were significantly higher in the trauma group ( $p=0.042)$, but no statistical significance was found in any subgroups of ADHD, ODD and CD.

Conclusion: Our results were in accordance with the vast majority of current literature in which ADHD was found to be significantly higher in the trauma group. ADHD must be considered in pediatric trauma patients to prevent possible extremity injuries.
\end{abstract}

Keywords: Pediatric trauma, extremity injury, attention deficit hyperactivity disorder, inattentive, hyperactive, impulsivity

\section{ÖZ}

Amaç: Dikkat eksikliği hiperaktivite bozukluğu (DEHB), çocukluk çağında tekrarlayan travma ve ekstremite yaralanmalarına en fazla neden olan nörogelişimsel bozukluktur. Karşıt olma karşı gelme bozukluğu (KOKGB) ve davranım bozukluğu (DB) ise DEHB'ye en sık eşlik eden durumlar olarak bilinmektedir. Çalışmamızda pediatrik travma hastalarında, ekstremite travmaları ve DEHB alt grupları arasındaki korelasyon, kontrol grubu ile karşılaştırılarak araştırılmıştır. Amacımız pediatrik ekstremite travmaları açısından yüksek riskli olguların saptanması ve erken tanı ile olası ekstremite yaralanmalarının önlenmesidir.

Gereç ve Yöntem: Eylül 2018-Şubat 2019 tarihleri arasında ekstremite yaralanması bulunan (grup 1) ve travmatik olmayan nedenlerle başvuran (grup 2) toplam 60 çocuk ardışık olarak çalışmaya dahil edildi. Katılımcılar Conners Ebeveyn Değerlendirme Ölçeği ve Güçler Güçlükler Anketi kullanılarak ön değerlendirmeye tabi tutuldu. Riskli olarak saptanan olgular Trakya Üniversitesi Tıp Fakültesi Hastanesi, Çocuk ve Ergen Ruh Sağlığı ve Hastalıkları Kliniği'ne detaylı değerlendirme için yönlendirildi.

Bulgular: DEHB tanısı alan olguların sayısı travma grubunda anlamlı olarak daha yüksek saptandı $(p=0,042)$, ancak DEHB alt grupları arasında ve KOKGB ve DB'yi karşılayan olgular arasında, pediatrik travma açısından anlamlı fark saptanmadı.

Sonuç: Bulgularımız, güncel literatürün büyük çoğunluğu ile uyumlu olup DEHB, travma grubunda anlamlı olarak daha yüksek saptanmıştır. Pediatrik travma hastalarında olası ekstremite yaralanmalarını önlemek için DEHB'ye dair semptomatoloji dikkate alınmalıdır.

Anahtar Kelimeler: Pediatrik travma, ekstremite yaralanması, dikkat eksikliği hiperaktivite bozukluğu, dikkatsizlik, hiperaktivite, dürtüsellik

Address for Correspondence: Leyla BOZATLI MD, Trakya University Medical Faculty Hospital, Department of Child and Adolescent Psychiatry, Edirne, Turkey Phone: +90 5057589368 E-mail: leylyabozatli@gmail.com ORCID ID: orcid.org/0000-0002-4701-4835

Received: 28.07.2020 Accepted: 25.12.2020

๑Copyright 2021 by the Tekirdağ Namık Kemal University Faculty of Medicine / Namık Kemal Medical Journal published by Galenos Publishing House. 


\section{INTRODUCTION}

Extremity injuries are one of the most important hospitalization causes in childhood'. The causes of pediatric trauma are multiple and psycho-social problems are one of them. Coincidental accidents are seen 1.5 times more in children with behavioral disorders than in others ${ }^{2}$. In the literature, attention deficit hyperactivity disorder (ADHD) is stated as a type of behavioral disorder which is the most common comorbid disease of pediatric trauma ${ }^{3}$.

ADHD is a neurodevelopmental disease, and it has three main symptoms including attention deficit, hyperactivity, and impulsivity ${ }^{4}$. Its prevalence is increasing and nearly genetic inheritance is seen in 79\% of the patients, which has been determined as the main etiological factor ${ }^{5}$. ADHD is the most common neurodevelopmental disorder in childhood and adolescence, which affects $3-5 \%$ of this population ${ }^{6}$. ADHD has three main subgroups as inattentive type (type 1), hyperactive-impulsive type (type 2) and the combined type (type 3). Oppositional defiant disorder (ODD) and conduct disorder (CD) are the most common comorbid conditions of ADHD.

ADHD is a chronic condition. The first step, which is very important, should be to develop a shared-care approach with the parents and child or adolescent, based on a shared understanding of identified treatment goals and preferences and accurate information about underlying etiology $y^{7}$. ADHD is associated with increased risk of unintentional injuries ${ }^{1-3,5,6}$. Our aim was to detect high-risk patients in pediatric extremity injuries, to prevent possible extremity injuries with early diagnosis and to ensure access to appropriate treatment options for ADHD.

\section{MATERIALS AND METHODS}

This prospective study was carried out at the outpatient clinic of Orthopedics and Traumatology in Turkish Minister of Health, Edirne Sultan $1^{\text {st }}$ Murat State Hospital from September 2018 to June 2019. The study was approved by the Institutional Medical Ethics Committee of the Medical Faculty Hospital of Trakya University (protocol no: TÜTF-BAEK 2018/226).

Patients between the ages of 6 and 15 years, who applied to the outpatient clinic of orthopedics and traumatology with their parents or legal representative, were included in the study. Patients were put into two groups as the trauma group (group 1) and the control (non-trauma) group (group 2) and they were questioned for their demographic data and medical histories (Table 1, 2). The trauma group consisted of patients who were directed by the emergency service and the non-trauma group consisted of patients who applied to the outpatient clinic for non-traumatic reasons (Table 3,4$)$. Thirty patients at each group, who had no history of psychiatric diagnosis and treatment, were consecutively included in the study. All patients were questioned and evaluated with the Conner's Parent Rating Scale (CPRS) and Strength and Difficulties Questionnaire (SDO). The CPRS was developed by Conners et al. ${ }^{8}$ to evaluate the behaviors of the child, and adaptation studies into Turkish were carried out by Kaner et al. ${ }^{9}$. It is seen that as the scores obtained from the scale increase, the severity of the symptoms increases. In our study, the scale was filled by the parent of the case. This scale was used to screen ADHD symptoms, and the group whose scale scores were found to be at risk was referred to the child and adolescent psychiatry outpatient clinic for Schedule for Affective Disorders and Schizophrenia for School-Age Children-Present and Lifetime Version (K-SADS$\mathrm{PL}$ ). The SDQ-Tur is a brief behavioral screening questionnaire developed by Robert Goodman in 1977. The Turkish validity and reliability study was conducted by Güvenir et al.. ${ }^{10}$. The survey aims to evaluate the behavior, emotions and relationships of children and adolescents. SDQ-Tur contains 25 questions about the positive and negative behavior characteristics. It contains 5 subheadings, each consisting of 5 questions; these subheadings are behavioral problems, emotional problems, attention deficit and hyperactivity, peer problems and social behaviors. In our study, this scale was used for ADHD screening.

Patients who received an initial diagnosis were evaluated by the Child and Adolescent Psychiatry Department of Trakya University Medical Hospital. During our study, patients still under follow-up and treatment with a diagnosis of ADHD were excluded from the study, considering the possible side effects of psychostimulant therapy on bone tissue. The cases who had not received ADHD diagnosis and treatment until that day were included in our study. Written informed consent was obtained from all patients.

\section{Statistical Analysis}

Statistical analyses were carried out with SPSS v.21.0 software (SPSS Inc., IBM Corporation, Armonk, New York, USA) and power analysis was carried out with G-Power v.3.1.9.4 software (Franz Faul, Universitat Kiel, Germany). For this study, alfa error was accepted as $5 \%$ and $p<0.05$ values were accepted as statistically significant. Before the study, a power analysis was

\section{Table 1. Demographic data}

\begin{tabular}{|c|c|c|c|c|}
\hline & Trauma & Non-trauma & p value \\
\hline \multirow{2}{*}{ Age } & Mean & 10.70 & 9.47 & $0.218^{1}$ \\
\hline & $\mathrm{SD}^{2}$ & 3.62 & 4.03 & - \\
\hline \multirow{2}{*}{ Gender } & Male & $15(25.0 \%)$ & $18(30.0 \%)$ & $0.604^{3}$ \\
\hline & Female & $15(25.0 \%)$ & $12(20.0 \%)$ & - \\
\hline \multirow{2}{*}{ BMI } & Normal & $29(48.3 \%)$ & $28(46.7 \%)$ & \\
\hline & Over-weight & $1(1.7 \%)$ & $2(3.3 \%)$ & $1.0000^{3}$ \\
\hline
\end{tabular}

1: Student's t-test, 2 : Standard deviation, ${ }^{3}$ : Chi-square test, BMI: Body mass index 
performed. Due to similar studies in the literature, statistical power (1- $\beta$ ) was accepted as $80 \%$ and the total sample size was determined as 60 patients. The groups were compared in terms of their demographic data, using the CPRS and SDQ for ADHD subgroups, ODD, and CD. Data were classified according to the distribution pattern. Parametric data were evaluated with the Student's t-test, non-parametric data were evaluated with the Mann-Whitney $U$ test, and categorical data were evaluated with the chi-square test.

\section{RESULTS}

The study was finished with 30 patients in each group. Group 1 consisted of 15 male and 15 female patients with the mean age of 10.70 years $( \pm 3.62)$ and group 2 consisted of 18 male and 12 female patients with the mean age of 9,47 years $( \pm 4.03)(p=0.604, p=0.218)$. Patients were classified as normal or overweight by using body mass index (BMI) calculations. BMI was calculated by dividing weight (in kilograms) by height (in meters) squared. There are different results in the literature about the relationship between trauma and BMI, and in our study, the groups were compared in terms of this variable 11 . One patient in group 1 and 2 patients in group 2 were overweight, so no significant difference was found $(p=1.000)$ in the trauma group, all patients were injured with direct and low-energy trauma and treated conservatively. In the trauma group, 18 patients had upper and 12 patients had lower extremity injuries. Also, the groups were compared for previous trauma history and no significant difference was found (6/30-12/30, $p=0.159)$. In addition to the CPRS and SDQ, patients were questioned for their or families' psychiatric medical histories and no statistical significance was found $(p=0.513, p=0.671)$. In the literature, socio-economic status (SES) and parents' educational levels were inversely proportional to trauma risk, so groups were compared in terms of SES and parents' (especially mother) educational levels. SES was classified as low, medium and high. Educational levels of parents were defined as illiterate, literate, elementary school, middle school, high school, university and postgraduate and no statistical significance was found $(p=1.000, p=0.754$, $\mathrm{p}=0.218)$ (Table 1, 2).

Patients who were diagnozed as ADHD were significantly higher in the trauma group ( $p=0.025)$ but no statistical significance was found for any subgroups of ADHD, ODD and CD by the CPRS or SDQ at the initial evaluations (Table 5,6 ).

Nineteen patients (31.7\%) whose scores were higher than the cut-off value with CPRS and SDO were examined by the Child

\section{Table 2. Medical history}

\begin{tabular}{|c|c|c|c|c|}
\hline & & Trauma & Non-trauma & p value ${ }^{1}$ \\
\hline Former trauma history & $\begin{array}{l}\text { No } \\
\text { Yes }\end{array}$ & $\begin{array}{l}24(40.0 \%) \\
6(10.0 \%)\end{array}$ & $\begin{array}{l}18(30.0 \%) \\
12(20.0 \%)\end{array}$ & $\begin{array}{l}0.159 \\
-\end{array}$ \\
\hline Socio-economic status & $\begin{array}{l}\text { Low } \\
\text { Medium } \\
\text { High }\end{array}$ & $\begin{array}{l}0(0.0 \%) \\
24(40.0 \%) \\
6(10.0 \%)\end{array}$ & $\begin{array}{l}0(0.0 \%) \\
23(38.3 \%) \\
7(11.7 \%)\end{array}$ & $\begin{array}{l}1.000 \\
- \\
-\end{array}$ \\
\hline Mother's educational level & $\begin{array}{l}\text { No literate } \\
\text { Literate } \\
\text { Elementary school } \\
\text { Middle school } \\
\text { High school } \\
\text { University } \\
\text { Postgraduate } \\
\end{array}$ & $\begin{array}{l}0(0.0 \%) \\
1(1.7 \%) \\
11(18.3 \%) \\
4(6.7 \%) \\
10(16.7 \%) \\
3(5.0 \%) \\
1(1.7 \%) \\
\end{array}$ & $\begin{array}{l}0(0.0 \%) \\
0(0.0 \%) \\
11(18.3 \%) \\
6(10.0 \%) \\
11(18.3 \%) \\
2(3.3 \%) \\
0(0.0 \%) \\
\end{array}$ & $\begin{array}{l}0.754 \\
- \\
- \\
- \\
- \\
- \\
- \\
\end{array}$ \\
\hline Father's educational level & $\begin{array}{l}\text { No literate } \\
\text { Literate } \\
\text { Elementary school } \\
\text { Middle school } \\
\text { High school } \\
\text { University } \\
\text { Postgraduate }\end{array}$ & $\begin{array}{l}0(0.0 \%) \\
0(0.0 \%) \\
11(18.3 \%) \\
4(6.7 \%) \\
6(10.0 \%) \\
5(8.3 \%) \\
4(6.7 \%)\end{array}$ & $\begin{array}{l}0(0.0 \%) \\
0(0.0 \%) \\
10(16.7 \%) \\
3(5.0 \%) \\
11(18.3 \%) \\
6(10.0 \%) \\
0\end{array}$ & $\begin{array}{l}0.218 \\
- \\
- \\
- \\
- \\
- \\
-\end{array}$ \\
\hline
\end{tabular}


and Adolescent Psychiatry Department of Medical Faculty Hospital of Trakya University with clinical assessment and "K-SADS-PL". After final evaluations, 11 patients (18.3\%) were diagnosed as ADHD. Patients who were diagnosed as ADHD were significantly higher in the trauma group $(p=0.042)$, but no statistical significance was found for any subgroups of ADHD, OD and CD (Table 7). Also, based on Chou et al. ${ }^{2}$ and Hurtig et al. ${ }^{12}$ studies, results were examined by the cut-off value of

\begin{tabular}{|l|l|}
\hline Table 3. Trauma group & 18 \\
\hline Upper extremity & 1 \\
\hline Shoulder contusion & 3 \\
\hline Elbow contusion & 5 \\
\hline Wrist contusion & 4 \\
\hline Distal radius fracture & 3 \\
\hline Phalanx contusion & 2 \\
\hline Phalanx fracture of hand & 12 \\
\hline Lower extremity & 2 \\
\hline Knee contusion & 6 \\
\hline Ankle contusion & 3 \\
\hline Foot contusion & 1 \\
\hline Phalanx fracture of foot & 30 \\
\hline Total & \\
\hline
\end{tabular}

\section{Table 4. Non-trauma group}

\begin{tabular}{|l|l|}
\hline Posture disorder & 6 \\
\hline Pes planovalgus & 5 \\
\hline Osgood Schlatter disease & 4 \\
\hline Scoliosis & 4 \\
\hline Severe disease & 3 \\
\hline Gait disturbance & 3 \\
\hline Mass in soft tissue & 3 \\
\hline Mass in bone & 2 \\
\hline Total & $\mathbf{3 0}$ \\
\hline
\end{tabular}

7 and the age of 12 years and no statistical significance was found (Table 8).

\section{DISCUSSION}

Several studies have tried to determine the relationship between ADHD and unintentional injuries in children ${ }^{1-3,5,6}$. Increased risk due to ADHD was controversial but the risk was statistically higher and there is consensus in the literature ${ }^{13-16}$. Chen at al. ${ }^{17}$ concluded that treatment longer than 6 months was associated with a lower risk for fracture among ADHD patients, but the overall risk is still higher than in the healthy population ${ }^{18}$ and ADHD treatment does not result in a decrease in the frequency of hospitalization ${ }^{19}$.

Brehaut et al. $^{16}$ reported that children with behavioral disorders had 1.5 times higher risk of injury compared to those without such disorders. A meta-analysis by Ruiz-Goikoetxea et al. ${ }^{13}$ indicated a significantly higher risk of injuries in ADHD compared to children or adolescents without ADHD [odds ratio (OR): 1.53]. In another study of Maxson et al. ${ }^{14}$, they investigated 6 to 12-year-old children who were admitted to the medical center for the treatment of an injury and appendicitis; the injured patient group was 3.25 times more likely to be positive for ADHD than appendicitis group. In another meta-analysis of 35 studies in children by Amiri et al. ${ }^{15}$, it was concluded that ADHD patients were injured nearly two times more than others (OR: 1.96). In our study, we calculated the OR as 4.35 at the first evaluation [OR: $4.35,95 \%$ confidence interval (CI): 1.320-14.504] and as 6 (OR: $6,95 \% \mathrm{Cl}: 1.172-30.725)$ at the final evaluation, which was higher compared to the literature but we concluded that the final evaluation by child and adolescent department eliminated the false-positive results in the non-trauma group and it is important. Also, in our study, no significance was found for any subgroups of ADHD or ODD and patients who diagnosed as ADHD were significantly higher in the trauma group $(p=0.042)$. In discordance with our study,

Table 5. Results of Conner's parent rating scale

\begin{tabular}{|c|c|c|c|c|}
\hline & & Trauma & Non-trauma & p value ${ }^{1}$ \\
\hline Type 1 ADHD (inattentive type) & $\begin{array}{l}\text { Healthy } \\
\text { Risky }\end{array}$ & $\begin{array}{l}23(38.3 \%) \\
7(11.7 \%) \\
\end{array}$ & \begin{tabular}{|l}
$28(46.7 \%)$ \\
$2(3.3 \%)$ \\
\end{tabular} & $\begin{array}{l}0.145 \\
- \\
\end{array}$ \\
\hline Type 2 ADHD (hyperactive-impulsive type) & $\begin{array}{l}\text { Healthy } \\
\text { Risky }\end{array}$ & \begin{tabular}{|l}
$25(41.7 \%)$ \\
$5(8.3 \%)$ \\
\end{tabular} & \begin{tabular}{|l}
$28(46.7 \%)$ \\
$2(3.3 \%)$ \\
\end{tabular} & $\begin{array}{l}0.424 \\
- \\
\end{array}$ \\
\hline Type 3 ADHD (combined type) & $\begin{array}{l}\text { Healthy } \\
\text { Risky }\end{array}$ & $\begin{array}{l}28(46.7 \%) \\
2(3.3 \%) \\
\end{array}$ & $\begin{array}{l}29(48.3 \%) \\
1(1.7 \%) \\
\end{array}$ & $\begin{array}{l}1.000 \\
- \\
\end{array}$ \\
\hline ADHD & $\begin{array}{l}\text { Healthy } \\
\text { Risky }\end{array}$ & $\begin{array}{l}16(26.7 \%) \\
14(23.3 \%) \\
\end{array}$ & $\begin{array}{l}25(41.7 \%) \\
5(8.3 \%) \\
\end{array}$ & $\begin{array}{l}0.025 \\
- \\
\end{array}$ \\
\hline Oppositional defiant disorder & $\begin{array}{l}\text { Healthy } \\
\text { Risky }\end{array}$ & $\begin{array}{l}27(45.0 \%) \\
3(5.0 \%) \\
\end{array}$ & $\begin{array}{l}29(48.3 \%) \\
1(1.7 \%) \\
\end{array}$ & $\begin{array}{l}0.612 \\
- \\
\end{array}$ \\
\hline Conduct disorder & $\begin{array}{l}\text { Healthy } \\
\text { Risky }\end{array}$ & $\begin{array}{l}29(46.7 \%) \\
1(1.7 \%)\end{array}$ & $\begin{array}{l}30(50.0 \%) \\
0(0.0 \%)\end{array}$ & $\begin{array}{l}1.000 \\
-\quad\end{array}$ \\
\hline
\end{tabular}


Karayağmurlu et al. ${ }^{20}$ concluded that all subgroups with ADHD and ODD were significantly increased in the trauma group compared to the control group for otorhinologic trauma.

Some studies concluded that ADHD's injury risk varied by age. Chou et al. ${ }^{2}$ compared 3,640 children with ADHD and 11,496 children without ADHD; no statistical significance was found for the risks of subsequent fracture in older age groups ( $\geq 12$ years old), but in younger age groups ( $5-12$ years old), ADHD group was significantly associated with increased risk of fractures compared to the non-ADHD group. In a cohort study by Hurtig et al. ${ }^{12}$, they investigated 6,111 children who were born in 1986. The risk for hospital-treated injuries was 1.7 times higher in younger age groups ( $\leq 7$ years old), which was statistically significant. Also, the ADHD group was treated more for injuries than the non-ADHD group considering older age groups, but no statistical significance was found for injuries except intoxication ${ }^{21}$. Contrary to these studies, we classified our results for cut-off ages of 7 and 12 years between the groups and no statistical significance was found in any subgroups or ADHD (Table 8). Low SES status is associated with high injury rates in children ${ }^{22}$. In our study, no statistical significance was found for SES ( $p=1.000$, Table 2).

Maxson et al. ${ }^{14}$, reported ADHD frequency as $29 \%$ in children who were admitted to emergency services due to injuries. Also our trauma group consisted of patients that were directed by the emergency service and our ADHD frequency was found to be $30 \%$, which is similar with that study.

In our study, we calculated the $\mathrm{OR}$ as 4.35 at the first evaluation (OR: 4.35, 95\% Cl: 1.320-14.504) and as 6 (OR: 6, 95\% Cl: 1.172-30.725) at the final evaluation, which is a higher value compared to the literature. In discordance with Chou et al. ${ }^{2}$ and Hurtig et al. ${ }^{12}$ studies, we classified our results for cut-off

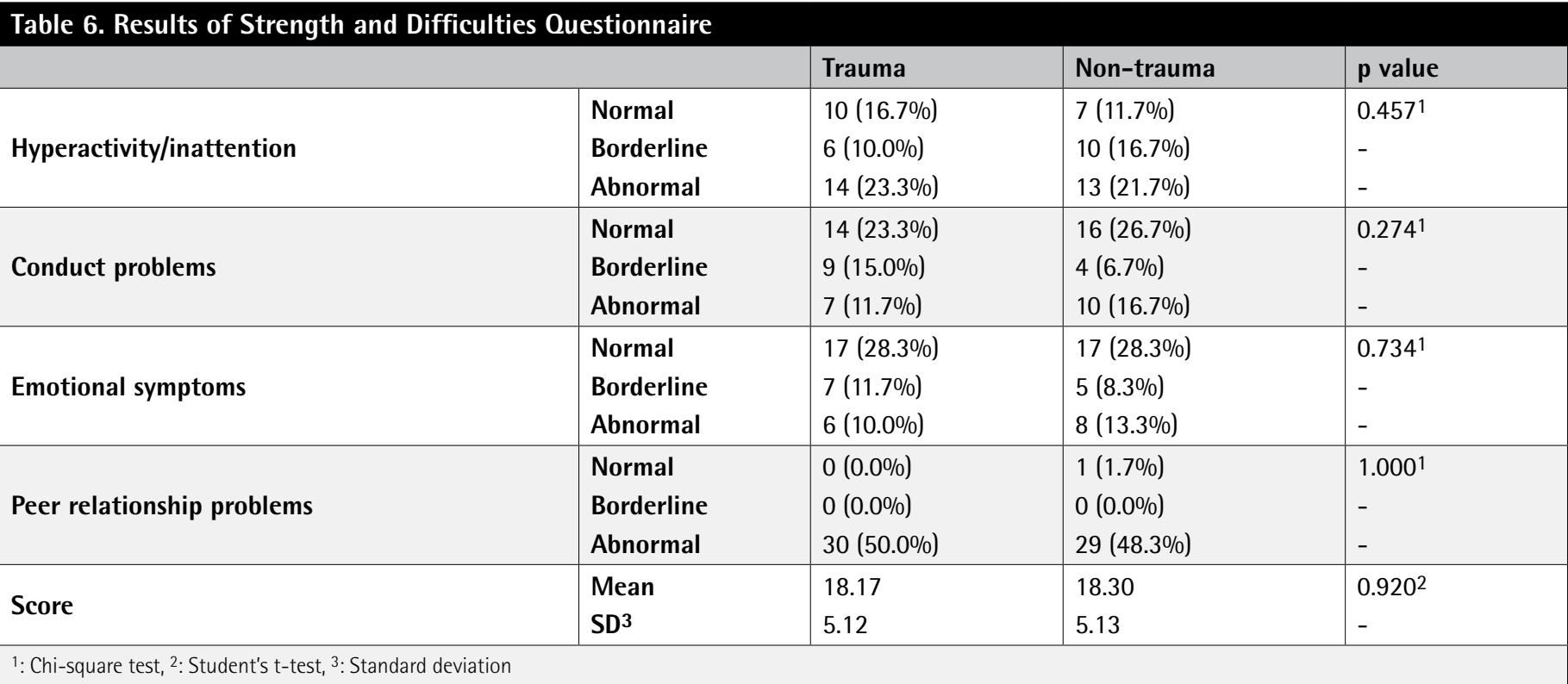

Table 7. Final evaluation

\begin{tabular}{|c|c|c|c|c|}
\hline & & Trauma & Non-trauma & p value ${ }^{1}$ \\
\hline Type 1 ADHD (inattentive type) & $\begin{array}{l}\text { Healthy } \\
\text { Diagnosed }\end{array}$ & $\begin{array}{l}25(41.7 \%) \\
5(8.3 \%)\end{array}$ & $\begin{array}{l}29(48.3 \%) \\
1(1.7 \%)\end{array}$ & $\begin{array}{l}0.195 \\
-\end{array}$ \\
\hline Type 2 ADHD (hyperactive-impulsive type) & $\begin{array}{l}\text { Healthy } \\
\text { Diagnosed }\end{array}$ & $\begin{array}{l}27(45.0 \%) \\
3(5.0 \%)\end{array}$ & $\begin{array}{l}29(48.3 \%) \\
1(1.7 \%)\end{array}$ & $\begin{array}{l}0.612 \\
-\end{array}$ \\
\hline Type 3 ADHD (combined type) & $\begin{array}{l}\text { Healthy } \\
\text { Diagnosed }\end{array}$ & $\begin{array}{l}29(48.3 \%) \\
1(1.7 \%) \\
\end{array}$ & $\begin{array}{l}30(50.0 \%) \\
0(0.0 \%)\end{array}$ & $\begin{array}{l}1.000 \\
- \\
\end{array}$ \\
\hline ADHD & $\begin{array}{l}\text { Healthy } \\
\text { Diagnosed }\end{array}$ & $\begin{array}{l}21(35.0 \%) \\
9(15.0 \%)\end{array}$ & $\begin{array}{l}28(46.7 \%) \\
2(3.3 \%)\end{array}$ & $\begin{array}{l}0.042 \\
- \\
\end{array}$ \\
\hline Oppositional defiant disorder & $\begin{array}{l}\text { Healthy } \\
\text { Diagnosed }\end{array}$ & $\begin{array}{l}30(50.0 \%) \\
0(0.0 \%)\end{array}$ & $\begin{array}{l}30(50.0 \%) \\
0(0.0 \%)\end{array}$ & $\begin{array}{l}1.000 \\
-\quad\end{array}$ \\
\hline Conduct disorder & $\begin{array}{l}\text { Healthy } \\
\text { Diagnosed }\end{array}$ & $\begin{array}{l}30(50.0 \%) \\
0(0.0 \%)\end{array}$ & $\begin{array}{l}30(50.0 \%) \\
0(0.0 \%)\end{array}$ & $\begin{array}{l}1.000 \\
-\end{array}$ \\
\hline
\end{tabular}


Table 8. Final evaluation with age

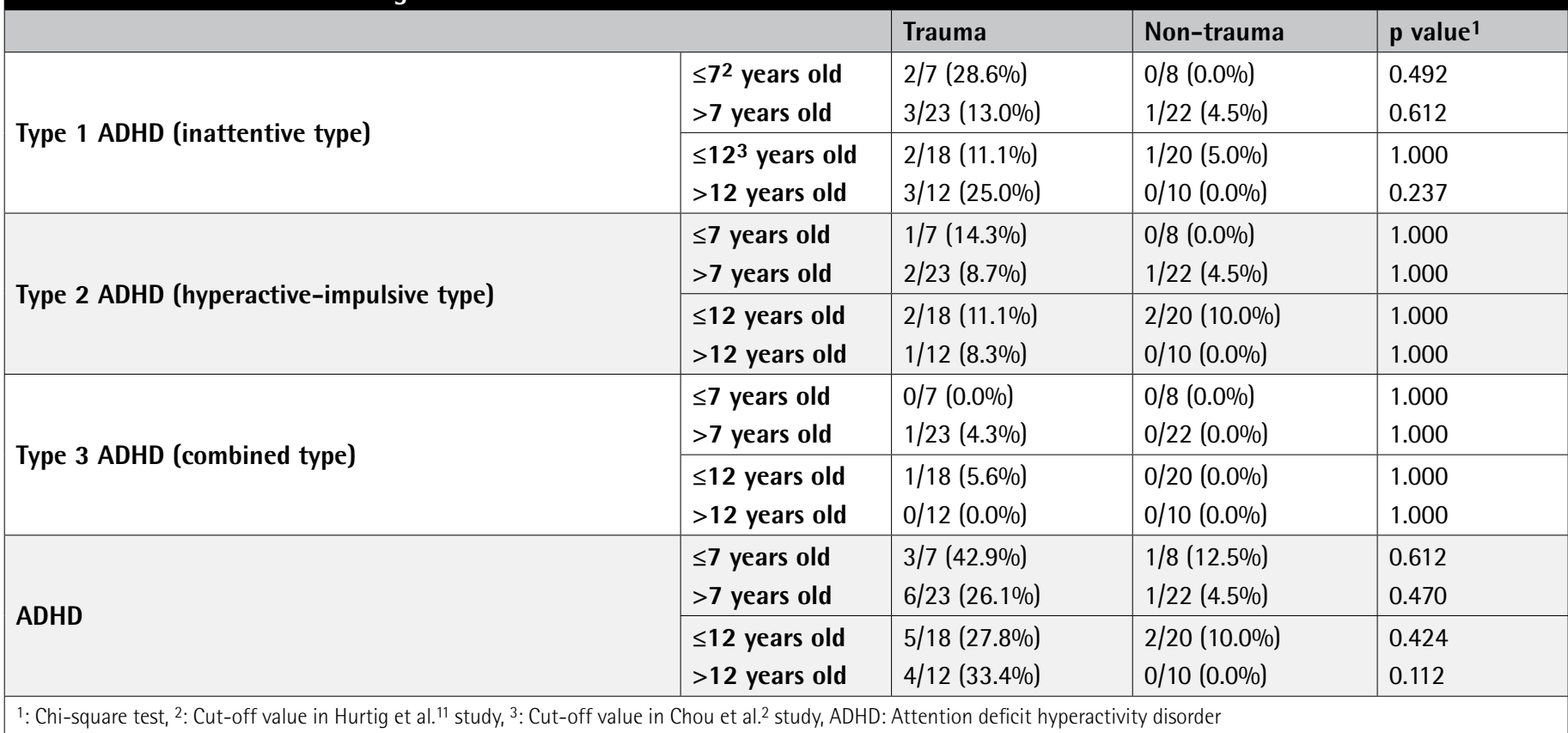

ages of 7 and 12 years between the groups and no statistical significance was found in any subgroups or ADHD (Table 7). In discordance with Karayağmurlu et al. ${ }^{20}$ study, no statistical significance was found for any subgroups of ADHD or ODD at the first and final evaluations.

\section{Study Limitations}

Pediatric extremity injuries, which have an important place in the daily routine of orthopedic outpatient clinics, affect the functionality of not only the child but the whole family, and it is especially important to evaluate recurrent extremity injuries in terms of etiology. In the planning phase of our study, our aim was to detect ADHD cases, which we considered as one of the possible causes of extremity injuries, to provide access to treatment and to prevent recurrence of extremity injuries. For this reason, the group that we considered as risky in terms of ADHD diagnosis in our study was determined as pediatric extremity injuries. The cases that were found to be at risk according to one of the two scales which we used for screening in our study were referred to the child and adolescent psychiatry outpatient clinic and these cases were evaluated with clinical interview and K-SADS application.

One of the important limitations of our study was that clinical interview and K-SADS could not be applied to each patient. The reason for this was that polyclinic working conditions were unfavorable for applying K-SADS to every patient due to the density. And the motivation of the pediatric patient group with orthopedic injuries and their parents for clinical interviews was insufficient. Another important limitation of our study was that only ADHD, CD and ODD diagnoses were evaluated due to the low number of patients who underwent K-SADS.

\section{CONCLUSION}

In the current study, we found that ADHD was diagnosed significantly higher in the trauma group, which is in concordance with the vast majority of literature. ADHD is also associated with a significantly increased risk of unintentional injuries ${ }^{1-3,5,6}$. Detection of the high-risk group in children examined for different types of traumas and referral of them directly to psychiatric evaluation are essential for the prevention of possible extremity injuries and for early diagnosis of ADHD.

\section{Ethics}

Ethics Committee Approval: The study was approved by the Institutional Medical Ethics Committee of the Medical Faculty Hospital of Trakya University (protocol no: TÜTF-BAEK 2018/226).

Informed Consent: Retrospective study.

Peer-review: Externally peer-reviewed.

\section{Authorship Contributions}

Surgical and Medical Practices: I.G.Ş., Z.A.Ş., L.B., Concept: I.G.Ş., L.B., I.G., Design: I.G., Z.A.Ş., L.B., Data Collection or Processing: I.G.Ş., Z.A.Ş., Analysis or Interpretation: I.G.Ş., Literature Search: I.G., Z.A.Ş., L.B., Writing: I.G.Ş., Z.A.Ş., L.B.

Conflict of Interest: No conflict of interest was declared by the authors.

Financial Disclosure: The authors declared that this study received no financial support. 


\section{References}

1. Uslu M, Uslu R, Eksioglu F, Ozen NE. Children with fractures show higher levels of impulsive-hyperactive behavior. Clin Orthop Relat Res. 2007;460:192-5.

2. Chou IC, Lin CC, Sung FC, Kao CH. Attention-deficit-hyperactivity disorder increases risk of bone fracture: a population-based cohort study. Dev Med Child Neurol. 2014;56:1111-6.

3. Ozer K, Gillani S, Williams A, Hak DJ. Psychiatric risk factors in pediatric hand fractures. J Pediatr Orthop. 2010;30:324-7.

4. Castellanos FX, Giedd JN, Berquin PC, Walter JM, Sharp W, Tran T, et al. Quantitative brain magnetic resonance imaging in girls with attentiondeficit/hyperactivity disorder. Arch Gen Psychiatry. 2001;58:289-95.

5. Faraone SV, Larsson H. Genetics of attention deficit hyperactivity disorder. Mol Psychiatry. 2019;24:562-75.

6. Centers for Disease Control and Prevention. Mental health in the United States: prevalence of diagnosis and medication treatment for attentiondeficit/hyperactivity disorder. United States, 2003.MMWR. 2005;54:842-7.

7. Feldman ME, Charach $A$, Bélanger SA. ADHD in children and youth: Part 2-Treatment. Paediatr Child Health. 2018;23:462-72.

8. Conners CK, Sitarenios G, Parker JD, Epstein JN. The revised Conners' Parent Rating Scale (CPRS-R): factor structure, reliability, and criterion validity. J Abnorm Child Psychol. 1998;26:257-68.

9. Kaner S, Buyukozturk S, Iseri E. Conners Parent Rating Scale-Revised Short: Turkish Standardization Study. Archives of Neuropsychiatry. 2013;50:100-9.

10. Güvenir T, Özbek A, Baykara B, Arkar H, Sentürk B,Incekas S. Psychometric Properties of The Turkish Version of The Strengths And Diffıculties Questionnaire, Çocuk ve Gençlik Ruh Sağlığı Dergisi. 2008;15:65-74.

11. Campbell J, Alqhatani A, McRae L, Kissoon N, Doan O. Body mass index and the odds of acute injury in children. Pediatr Emerg Care. 2013;29:21-5.

12. Hurtig $T$, Ebeling $H$, Jokelainen J, Koivumaa-Honkanen $H$, Taanila A. The Association Between Hospital-Treated Injuries and ADHD Symptoms in Childhood and Adolescence: A Follow-Up Study in the Northern Finland Birth Cohort 1986. J Atten Disord. 2016;20:3-10.
13. Ruiz-Goikoetxea M, Cortese $S$, Aznarez-Sanado M, Magallón S, Alvarez Zallo $\mathrm{N}$, Luis EO, et al. Risk of unintentional injuries in children and adolescents with ADHD and the impact of ADHD medications: A systematic review and meta-analysis. Neurosci Biobehav Rev. 2018;84:63-71.

14. Maxson RT, Lawson KA, Pop R, Yuma-Guerrero P, Johnson KM. Screening for attention-deficit/hyperactivity disorder in a select sample of injured and uninjured pediatric patients. J Pediatr Surg. 2009;44:743-8.

15. Amiri S, Sadeghi-Bazargani H, Nazari S, Ranjbar F, Abdi S. Attention deficit/ hyperactivity disorder and risk of injuries: A systematic review and metaanalysis. J Inj Violence Res. 2017;9:95-105.

16. Brehaut JC, Miller A, Raina P, McGrail KM. Childhood behavior disorders and injuries among children and youth: a population-based study. Pediatrics. 2003;111:262-9.

17. Chen VC, Yang YH, Liao YT, Kuo TY, Liang HY, Huang KY, et al. The association between methylphenidate treatment and the risk for fracture among young ADHD patients: a nationwide population-based study in Taiwan. PLoS One. 2017;12:1-11.

18. van den Ban $E$, Souverein $P$, Meijer W, van Engeland $H$, Swaab $H$, Egberts $T$ et al. Association between ADHD drug use and injuries among children and adolescents. Eur Child Adolesc Psychiatry. 2014;23:95-102.

19. Mikolajczyk R, Horn J, Schmedt N, Langner I, Lindemann C, Garbe E. Injury prevention by medication among children with attention-deficit/ hyperactivity disorder: a case-only study. JAMA Pediatr. 2015;169:391-5.

20. Karayağmurlu A, Aytaç I, Gülşen S. Relationship between otorhinologic trauma and Attention Deficit Hyperactivity Disorder symptoms in children. Int J Pediatr Otorhinolaryngol. 2019;120:89-92.

21. Gautam M, Prabhakar D. Stimulant Formulations for the Treatment of Attention-Deficit/Hyperactivity Disorder. Prim Care Companion CNS Disord. 2018;20:18r02345.

22. Marcin JP, Schembri MS, He J, Romano PS. A population-based analysis of socioeconomic status and insurance status and their relationship with pediatric trauma hospitalization and mortality rates. Am J Public Health. 2003;93:461-6. 